\title{
INVESTIGATING THE INFLUENCE OF PERSONAL TRAITS ON RELATIONSHIP BETWEEN LEADER AND MEMBER IN TOURISM AND PUBLIC SECTOR
}

\author{
Igor Stamenković ${ }^{1}$ (D) \\ Tatjana Vanić ${ }^{2}$ \\ Tamara Gajić ${ }^{3}$
}

DOI: https://doi.org/10.31410/tmt.2019.617

\begin{abstract}
This study examines the effect of a certain personality dimensions and relationships between leaders and followers in the context of tourism and the public sector. It also highlights the fact that the personal characteristics of the employees are important for the organization and can be a ,tool" for improving the organizational and operational performance. The analysis included 200 respondents in the services sector (tourism and public sector in Serbia). The tourism sector is characterized by entrepreneurial skills of the owner and the ability to market positioning, while the public sector operates within the legal norms in the service of the citizens. In order to achieve the goals of the research, for the analysis of independent T-test, correlation and regression were used. These findings can be used in the implementation of new techniques in organizational contexts.
\end{abstract}

Keywords: Personal traits, LMX, BFI, Tourism, Public Sector, Service Sector.

\section{INTRODUCTION}

$I^{n}$ $n$ order to understand and predict the behavior in the working environment is necessary to know the personal characteristics of employees. Personal characteristics play a significant role in predicting and explaining organizational behavior. One way is to directly ask a person about his / her characteristics, while others ask the other person what he / she saw the person. Of course, there are some exception in both cases.

In economic terms, the decisions that individuals make and the outcomes of those decisions can have significant consequences, because the personality seen as cognition. According to Costa and McCrae (1990) personality traits are defined as dimension of the individual differences in order to demonstrate the consistent thought, emotion, and action. In the personality, the nomenclature allows researchers to study a specific domain related trait, rather than to separately examine the thousands of individual attributes (Allport \& Odbert, 1936) that make up the human beings and unique to individuals (John, Neumann, \& Soto, 2008).

Relations between leaders and followers are important for the organization, because the LMX theory is based on the concept of different relationships, where leaders in the working environment are formed two groups of followers according to how they are treated (Danserau et al., 1975; Grean \& Scandura, 1987). The high level of exchange involves a high degree of mutual trust (Graen \& Uhl-Bien, 1995). Theory of leader and follower exchange (Graen et al., 1982;

\footnotetext{
1 Department of Geography, Tourism and Hotel Management, Faculty of Sciences, University of Novi Sad, Trg Dositeja Obradovića 3, 21000 Novi Sad, Serbia

2 City Administration for Economy - City of Novi Sad, Rumenačka 110a, 21000 Novi Sad, Serbia

3 Novi Sad School of Business, Vladimira Perića - Valtera 4, 21000 Novi Sad, Serbia
} 
Graen \& Scandura, 1987; Graen \& Uhl-Bien, 1995) investigate the association relations in organization and their outcomes. The analysis of three domains: leader, follower, and relation (bond), Graen and Uhl-Bien (1995) were combining the above mentioned domains and defined what influences the improvement of the efficiency of leadership in certain situations, that is, which one of the characteristics can be developed to achieve the specific of results.

\section{LITERATURE REVIEW}

\section{1. $\mathbf{L M X}$}

The very concept of leadership is as old as human civilization, and numerous studies have not provided a clear picture of what is leadership. Many theories studied different aspects of leadership, but what unites them is that researchers are trying to shape a theory in which all the positive aspects maximized and negative minimize (Graen \& Ulh-Bien, 1995). Contrary to all previous theories, the early 70 s of the 20 th century presented new studies that have been marked as a theory of exchange leaders and followers or LMX Theory. Day and Mishchenko (2015) in his study of LMX theory suggests that as one of the most influential theories of leadership for the last four decades. In order to explain the relationship leader-employed, researchers have used a variety of approaches, from the vertical of dyad connection (Danserau et al, 1975; Grean \& Cashman 1975) and the theory of the social exchange (Wayne \& Green, 1993) to the Relational Leadership Theory - RLT (Uhl-Bein, 2006).

Before establish model LMX, as well as the very beginning of its development, the researches included the individual characteristics (personalities, similar characteristcs, etc.) (Dienesch \& Liden, 1986), where the focus was on a variety of two-member interactions in which the leader develops equal relation with employees. Further development of LMX included job characteristics, because the type of work has a certain impact on the exchange leaders and followers (Graen \& Ulh-Bien, 1995). Liden and associates (1997) explains that a high level of LMX improves the sense of the mutual commitments, as well as the emotional attachment between the leader and follower, and work relations based on social exchange characterized by loyalty, commitment and support (Erdogan \& Liden, 2002).

Since LMX is the center of exchange between two people, we should know that certain types (characteristics) employees match or not in relations with the leader (Bernerth et al, 2008). The same group of researchers points out that the combination of different personality types allows different approach to the work tasks, solve problems, but also contributes to the overall results of the organization. In defining the contribution of employees, it is important to develop their functional roles, as well as a superior understanding (George \& Hançerli, 2004). Perception and responsibility of followers has a significant contribution to the relations with the leader. The leader (his/her personal characteristics) drives employee relations, and the results depend on the quality of the connection, i.e. the quantity of engagement that will make the other members of the group. Since each member has its own methods of work, in the group would find many different types of personalities. Significant difference to LMX relations is recorded in the management of large groups, where the leader should present all the positive side of leader-member exchange (Schyns et al, 2012).

In the study of LMX antecedents has been found that the behavior associated with extraversion, agreeableness and conscientiousness, and to influence the development of high quality LMX relation (Liden et al, 1997; Barrick \& Mount, 1991; Costa \& McCrae, 1988). By contrast, the 
leader or a member who feels that his / her partner is not able to respond to challenges, and to return the same, it is less likely to spend time, trust, and in particular respect that can be found in high-quality LMX (Bernerth et al, 2008). Contribution to high-quality exchange of LMX has openness which is also called intellect. People high on openness have a wide range of coping, but prefer specific solutions to problems in stressful situations (Grant \& Langan-Fox, 2007). As for the emotional stability, if only one member is neurotic, exchange leaders and followers there will be an imbalance, and relations will be of low-quality.

Predictors of LMX quality were studied characteristics of personality and leaders and employees. Agreeableness and conscientiousness although slightly, show the relation between BFI model and LMX for managers (Bernerth et al, 2008). Also, predictor of LMX quality is extraversion for a particular level of managers (top level). Barrick and Mount (1991) considered that the extravert useful for managerial jobs, but not for each type of job such as secretary, engineer, architect, accountant.

\subsection{Personal traits, sectors and LMX}

In assessing the overall operational performance increasingly used the results related to the theory of personality. Work environment requires constant interaction because it is composed of people who have their own system of values, needs, biographical characteristics, personality traits, self-esteem, perception of the environment, objectives and a number of other variables that affect organizational behavior. These personal variables have a direct and indirect (moderating and mediating) the impact on organizational outcomes.

Personality is defined as an acceptable stable characteristic of individuals, which affects their behavior and cognition (Colquitt et al, 2000). Also, the personal characteristics have been developed and as the tendency of individuals to behave in certain ways in certain situations (Chamorro-Premuzić \& Furnham, 2005).

Number of researchers, and various types of samples, as well as the method in the study of personal characteristics, resulting of model of the Big Five Inventory (Goldberg, 1990; Costa \& McCrae, 1992; John \& Srivastava, 1999). The aforementioned five-factor model has enabled researchers in the fields of organizational psychology and human resource management to examine personality traits with the variables of organizational behavior. Theoretically, the BFI model starts from the assumption that the important personal characteristics, because they affect the way individuals behave in a certain environment. According to John and Srivastava (1999) scientific objectives taxonomy is a comprehensive definition of the domain in which there are a number of specific cases that could be understood in a very simple way. Big Five personality dimensions with minor variations accepted by most researchers, including:

Extraversion - talkativeness, entertaining, energy and sociability. People with high levels of extraversion characterized establishing relationships with a large number of people, socially engaged, looking for excitement, radiate optimism, positive attitudes, respect others and are very friendly (Louis, 1980; Mayer \& Allen, 1991). Type of work that is done in the tourism and the public sector is directly related to contacts with people. Warmth and energy are two positive and necessary characteristics for successful work with the users of public and tourist services. For a tourist, rather than for the public sector, one of the qualities that should definitely be a communication, but also a desire for new challenges and good outcomes causing stronger and 
better relations with the manager. Unlike extravert, introvert is reserved, suspicious and often alone than in a group. In the organizational context, extroverts want to establish interaction with members of the organization, have good relations with them and seek challenging tasks of managers. Extroversion in research and positively connected to the leadership, so they are referred to as leaders` extraverts in groups (Judge et al, 2002).

Agreeableness - gratitude, forgiveness, generous, likeability, confidentiality. This dimension is associated with people who voluntarily work with other colleagues (Mount \& Barrick, 1991) and are very flexible. Persons with a high degree of comfort are altruist, genuine, they behave in an appropriate manner, modest, but they prefer to be cooperative (Judge et al, 2002). Pleasant people are more motivated to achieve interpersonal contacts, resulting in good operating performance and teamwork. For employees in the public sector the most important in meeting the people that are kind and listen to the problem. On the other hand, in the tourism sector due to the nature of work requires a high level of interpersonal action, especially in hospitality. The negative context, people were skeptical in relation to the intentions of others, put to the top priorities the personal interests and it is quite a difficult to work with them. Researchers (Piedmont et al, 1991; Yukl, 1998; Judge et al, 2002) analyzed the agreeableness and leadership find out that the possible relationship is uncertain, i.e. it can be problematic. Negative and positive attributes of agreeableness are significant in the service sectors because it characterized by a close encounter with the customer.

Conscientiousness - efficiency, organization, reliability, responsibility. Conscientiousness is linked with the overall work performance, but also with efficiency of leaders (Barrick \& Mount, 1991). People with high on conscientiousness dimension respect the rules and norms that have competencies and achieve the set goals, and they are characterized by more self-discipline, productivity, responsibility and independence (Costa \& McCrae, 1992; John \& Srivastava, 1999; Teng, 2008). In the organizational context, these people have a strong will, precisely and accurately perform tasks following the rules. In contrast, people who are negative on conscientiousness start multiple jobs at once, and they are very superficial and unsystematic. For the realization of public sector jobs, a priority responsibility and thoroughness with respect for the rules. In the first place, providing tourist services are the organization and reliability (selling tourist packages, tourist guiding services, hospitality/catering services). Low dimension on conscientiousness in both sectors can have very unpleasant consequence (lost file that has a time limit for conclusion, a patient who did not arrive for review at the scheduled time, double charged for room in the same accommodation facilities, etc.). High dimension on conscience is one of the best predictors of good operating performance, which has the consequence of good relation with the leader(s) (Barrick \& Mount, 1991).

Neuroticism - anxiety, tension, instability and concern. Also referred to as emotional stability. Costa and McCrae (1992) emphasize that the extent continuum between stability and instability, and that is most commonly used for analyzing personality. The high degree of negative affectivity are people who are tend to anxiety, have irrational ideas which not able to control their impulses and tend to depression, constantly worried and often subject to stress (Judge et al, 2002). In the organizational context of the high level of neuroticism causes frequent conflicts between superiors and subordinates. Individual with low on negative affectivity dimension is characterized by stability and composure, and easier to „cope” in stressful situations. Although there are conflicting opinions in a number of researchers, may be considered to be a high-degree of negative affectivity not favorable organizational outcomes in the service sectors since resulted in a lower level of job satisfaction. 
Openness - esthete, curiosity, imaginary, originality, wider interests. It is also called openness for experience. By studying all five dimensions, Bass (1990) signaled openness as a characteristic that has the best relationship with leadership. A person who are high on openness has broad interests, values intellectual ability, acceptance of new ideas and views and is very creative. Very important skill for an effective leader is creativity (Judge et al, 2002). In the organization context, employee may come into conflict situations with the supervision if he/she is low on openness. People who low on openness do not explore, keep under control their emotions and accept very narrow circle of reciprocity. A high dimension on openness was primarily related to the tourism sector which, without originality, curiosity and interest does not contribute to better working performance, thereby minimizing organizational result.

The results of numerous studies have confirmed that the impact of employee personality traits important for contextual performance, and less on performance related to the immediate task. Summarizing from the above, analyzing personality according to modelled BFI can be a predictor of certain life outcomes, such as leadership (high level of extraversion), helping others (high level of agreeableness), education level (conscientiousness), tendency to depression (high level of neuroticism) and creativity (high level of openness).

Hypothesis One: There are sectoral and gender differences in relations LMX and BFI.

Hypothesis Two: LMX is positively correlated with extraversion, agreeableness, conscientiousness and openness, and negatively correlated with neuroticism in tourism and public sector.

Hypothesis Three: Predictors LMX are dimensions of personality by model BFI in tourism and the public sector.

\section{METHODOLOGY}

\subsection{Instruments}

The most commonly used for the questionnaire research of the relationship leader and follower according Grean and Uhl-Bien (1995) model LMX 7. Measurements can be a five-point Likert scale from 1-very poor to 5-good. The questionnaire is homogeneous and contains seven questions. Interpretation of the results obtained in the relations between leaders and followers include the following: very high 30-35, high 25-29, 20-24 moderate, low 15-19 and very low 7-14. Cronbach alpha for said questionnaire is high $(\alpha=.94)$. The questionnaire was filled in by all levels except the highest, that is, without owner (tourism sector) and Mayor/Council members/ directors in the public sector.

Big Five Inventory questionnaire (BFI) is measured rating different personal traits by John and his associates (1991); John and Srivastava (1999). The questionnaire contains 44 questions and has five dimensions: extraversion, agreeableness, conscientiousness, neuroticism and openness (McCrae \& John, 1991), and was measured with a five-point Likert scale (1-strongly disagree to 5-strongly agree). The results are obtained for each dimension based on the arithmetic mean, and Cronbach alpha is in the range of $\alpha=0.69$ to $\alpha=0.79$. 


\subsection{Procedure}

The analysis of the data was used statistical package SPSS 22.0. The data obtained were analyzed using descriptive statistics, then Pearson correlation coefficients were determined by connections/relations for the indicated variables, whereas the regression examined the contribution of each predictor variable in explaining the criterion variable. Independent T-test was used to determine whether there are differences between the variables of age and sector. Reliability of the data obtained according to the same questionnaires calculated Cronbach`s alpha.

\subsection{Sample}

The questionnaire received 270 employees in the service sector (travel agencies, hotels, restaurants, coffee - bars, public enterprises, city administration) and 200 questionnaires returned filled (74\%). Distribution of the questionnaire was conducted electronically and analogically in Serbia, from January till March, 2016. The sample was comprised of 64\% women and 36\% men, average age is 38.2 , and the highest $41 \%$ of respondents from the age groups ,30-41". Of the total number of received questionnaires, respondents did not fill the 9 years of age (4\%), i.e. 5 patients from the tourist sector and 4 from the public sector.

\section{RESEARCH RESULTS}

Detailed population statistics by type of sector data in the following table.

Table 1. Demographic characteristics of the sample

\begin{tabular}{|c|c|c|c|c|}
\hline \multirow{2}{*}{ Category } & \multirow{2}{*}{ Description } & Tourism & Public & \multirow{2}{*}{$\%$} \\
\hline & & $\mathbf{N}$ & $\mathbf{N}$ & \\
\hline \multirow{2}{*}{ Gender } & Male & 42 & 30 & 36.0 \\
\hline & Female & 58 & 70 & 64.0 \\
\hline \multirow{4}{*}{ Age* } & $18-29$ & 36 & 7 & 21.5 \\
\hline & $30-41$ & 42 & 40 & 41.0 \\
\hline & $42-53$ & 14 & 30 & 22.0 \\
\hline & $54-65$ & 3 & 19 & 11.0 \\
\hline \multirow{6}{*}{ Education } & Primary & 1 & 0 & 0.5 \\
\hline & Secondary & 18 & 13 & 15.5 \\
\hline & College & 24 & 4 & 14.0 \\
\hline & University & 50 & 61 & 55.5 \\
\hline & MSc & 6 & 15 & 10.5 \\
\hline & $\mathrm{PhD}$ & 1 & 7 & 4.0 \\
\hline \multirow{4}{*}{ Tenure } & Up to 10 & 69 & 35 & 52.0 \\
\hline & $11-20$ & 18 & 39 & 28.5 \\
\hline & $21-30$ & 8 & 18 & 13.0 \\
\hline & $31+$ & 5 & 8 & 6.5 \\
\hline
\end{tabular}

*5 missing in tourism sector, 4 missing in public sector.

Source: Authors' calculations

T-test analysis of the sector structure shows the difference for four of the six variables. The results obtained indicate that the tourist sector $(\mathrm{M}=3.40, \mathrm{SD} t=1.01)$ is higher than the public sector $(\mathrm{M}=2.89, \mathrm{SD}=1.02), \mathrm{t}(198)=3.54, \rho=.00, \mathrm{~d}=.06$ (medium effect size) the relation of leaders and followers. Then, the tourist sector $(\mathrm{M}=3.71, \mathrm{SD}=.47)$ greater than the public sector $(\mathrm{M}=3.53, \mathrm{SD}=.56), \mathrm{t}(198)=2.49, \rho=.01, \mathrm{~d}=.03$ (small size effect) for extraversion. Tourism 
sector $(\mathrm{M}=4.05 \mathrm{SD}=.48)$ greater than the public sector $(\mathrm{M}=3.92, \mathrm{SD}=.41), \mathrm{t}(198)=2.18, \rho=$ $.03, \mathrm{~d}=.02$ (small size effect) for agreeableness. Result has neuroticism, showing that the public sector $(\mathrm{M}=2.74, \mathrm{SD}=.68)$ higher than the tourist sector $(\mathrm{M}=2.51, \mathrm{SD}=.65), \mathrm{t}(198)=-2.54$, $\rho=.01, \mathrm{C}=.03$ (small size effect).

Table 2. T-test for sectors

\begin{tabular}{|c|c|c|c|c|c|c|c|c|}
\hline \multirow{2}{*}{ Variables } & \multicolumn{3}{|c|}{ Group statistics } & \multicolumn{2}{|c|}{ Levene's test } & \multicolumn{3}{|c|}{ t-test } \\
\hline & Group & $\mathbf{M}$ & SD & $\mathbf{F}$ & $\rho$ & $\mathbf{t}$ & df & $\rho$ \\
\hline \multirow{2}{*}{ LMX } & Tourism & 3.40 & 1.01 & \multirow{2}{*}{.29} & \multirow{2}{*}{.59} & \multirow{2}{*}{3.54} & \multirow{2}{*}{198} & \multirow{2}{*}{.00} \\
\hline & Public & 2.89 & 1.02 & & & & & \\
\hline \multirow{2}{*}{ Extraversion } & Tourism & 3.71 & .47 & \multirow{2}{*}{2.76} & \multirow{2}{*}{.09} & \multirow{2}{*}{2.49} & \multirow{2}{*}{198} & \multirow{2}{*}{.01} \\
\hline & Public & 3.53 & .56 & & & & & \\
\hline \multirow{2}{*}{ Agreeableness } & Tourism & 4.05 & .48 & \multirow{2}{*}{1.70} & \multirow{2}{*}{.19} & \multirow{2}{*}{2.18} & \multirow{2}{*}{198} & \multirow{2}{*}{.03} \\
\hline & Public & 3.92 & .41 & & & & & \\
\hline \multirow{2}{*}{ Conscientiousness } & Tourism & 4.28 & .48 & \multirow{2}{*}{3.98} & \multirow{2}{*}{.04} & \multirow{2}{*}{1.32} & \multirow{2}{*}{198} & \multirow{2}{*}{.19} \\
\hline & Public & 4.19 & .53 & & & & & \\
\hline \multirow{2}{*}{ Neuroticism } & Tourism & 2.51 & .65 & \multirow{2}{*}{.11} & \multirow{2}{*}{.74} & \multirow{2}{*}{-2.51} & \multirow{2}{*}{198} & \multirow{2}{*}{.01} \\
\hline & Public & 2.74 & .68 & & & & & \\
\hline \multirow{2}{*}{ Openness } & Tourism & 3.47 & .42 & \multirow{2}{*}{2.40} & \multirow{2}{*}{.12} & \multirow{2}{*}{-.81} & 108 & ? \\
\hline & Public & 3.53 & .47 & & & & 190 & .42 \\
\hline
\end{tabular}

F-statistics; $\rho$-value (Sig.) $>.05$; t-value of t-test; df-degrees of freedom; $\rho$-value $(\mathrm{Sig})<.05$.

Source: Authors' calculations

Examination of the differences of gender structure following results were obtained. Female groups $(\mathrm{M}=3.68, \mathrm{SD}=.51)$ greater than the male groups $(\mathrm{M}=3.52, \mathrm{SD}=.52), \mathrm{t}(198)=-2.08$, $\rho=.04, d=.02$ (small size effect) for extraversion. The results for the agreeableness show that a group of male and female $(\mathrm{M}=4.04, \mathrm{SD}=.42)$ higher than the male groups $(\mathrm{M}=3.89, \mathrm{SD}=$ $.50), \mathrm{t}(198)=-2.15, \rho=.03, \mathrm{~d}=.02$ (small size effect). Also, even for conscientiousness female groups $(\mathrm{M}=4.32, \mathrm{SD}=.44)$ higher than the male groups $(\mathrm{M}=4.10, \mathrm{SD}=.59), \mathrm{t}(198)=-2.77, \rho$ $=.01, \mathrm{~d}=.04$ (small size effect).

Table 3. T-test for gender

\begin{tabular}{|c|c|c|c|c|c|c|c|c|}
\hline \multirow{2}{*}{ Variables } & \multicolumn{3}{|c|}{ Group statistics } & \multicolumn{2}{|c|}{ Levene's test } & \multicolumn{3}{|c|}{ t-test } \\
\hline & Group & $\mathbf{M}$ & SD & $\mathbf{F}$ & $\rho$ & $\mathbf{t}$ & df & $\rho$ \\
\hline \multirow{2}{*}{ Extraversion } & Male & 3.52 & .52 & \multirow{2}{*}{.01} & \multirow{2}{*}{.93} & \multirow{2}{*}{-2.08} & \multirow{2}{*}{198} & \multirow{2}{*}{.04} \\
\hline & Female & 3.68 & .51 & & & & & \\
\hline \multirow{2}{*}{ Agreeableness } & Male & 3.89 & .50 & \multirow{2}{*}{1.71} & \multirow{2}{*}{.19} & \multirow{2}{*}{-2.15} & \multirow{2}{*}{198} & \multirow{2}{*}{.03} \\
\hline & Female & 4.04 & .42 & & & & & \\
\hline \multirow{2}{*}{ Conscientiousness } & Male & 4.10 & .59 & \multirow{2}{*}{8.46} & \multirow{2}{*}{.00} & \multirow{2}{*}{-2.77} & \multirow{2}{*}{198} & \multirow{2}{*}{.01} \\
\hline & Female & 4.32 & .44 & & & & & \\
\hline \multirow{2}{*}{ Neuroticism } & Male & 2.62 & .74 & \multirow{2}{*}{2.40} & \multirow{2}{*}{.13} & \multirow{2}{*}{-.07} & \multirow{2}{*}{198} & \multirow{2}{*}{.94} \\
\hline & Female & 2.63 & .63 & & & & & \\
\hline \multirow{2}{*}{ Openness } & Male & 3.48 & .45 & \multirow{2}{*}{.01} & \multirow{2}{*}{.92} & \multirow{2}{*}{-.40} & \multirow{2}{*}{198} & \multirow{2}{*}{.70} \\
\hline & Female & 3.51 & .44 & & & & & \\
\hline
\end{tabular}

F-statistics; $\rho$-value (Sig.) $>.05$; t-value of t-test; df-degrees of freedom; $\rho$-value $(\mathrm{Sig})<.05$.

Source: Authors' calculations

The level of LMX and personality traits of conscientiousness and openness shows a significant positive correlation in the tourism sector. Within the public sector, a positive correlation between the level of LMX and personality traits of extraversion $(\mathrm{r}(100)=0.22, \rho<0.05)$, a negative correlation between the levels of exchange of the leader and follower, and dimensions neuroticism $(\mathrm{r}(100)=-0.25, \rho<0.05)$. 
Table 4. Correlations among variables per sectors

\begin{tabular}{|l|c|c|}
\hline \multirow{2}{*}{ Variables } & \multicolumn{2}{|c|}{ LMX } \\
\cline { 2 - 3 } & Tourism & $.22^{*}$ \\
\hline Extraversion & .12 & .12 \\
\hline Agreeableness & .13 & .04 \\
\hline Conscientiousness & $.22^{*}$ & $-.25^{*}$ \\
\hline Neuroticism & -.08 & -.01 \\
\hline Openness & $.20^{*}$ & \multicolumn{2}{|c|}{ Public } \\
\hline
\end{tabular}

*Correlation is significant at the .05 level.

Source: Authors' calculations

Table 5. Multiple regressions model per sector

\begin{tabular}{|c|c|c|c|c|c|}
\hline & Tourism sector & Variables & $\beta$ & $\mathbf{t}$ & $\rho$ \\
\hline \multirow{2}{*}{$\mathbf{R}^{2}$} & \multirow{2}{*}{.08} & Extraversion & -.03 & -.29 & .77 \\
\hline & & Agreeableness & .03 & .24 & .82 \\
\hline \multirow{2}{*}{$\mathbf{F}$} & \multirow{2}{*}{1.58} & Conscientiousness & .20 & 1.64 & .11 \\
\hline & & Neuroticism & .05 & .43 & .67 \\
\hline \multirow[t]{2}{*}{$\rho$} & .18 & Openness & .18 & 1.59 & .12 \\
\hline & Public sector & Variables & $\beta$ & $\mathbf{t}$ & $\rho$ \\
\hline \multirow{2}{*}{$\mathbf{R}^{2}$} & \multirow{2}{*}{.10} & Extraversion & .22 & 1.80 & .08 \\
\hline & & Agreeableness & -.03 & -.23 & .82 \\
\hline \multirow{2}{*}{$\mathbf{F}$} & \multirow{2}{*}{2.00} & Conscientiousness & -.04 & -.30 & .77 \\
\hline & & Neuroticism & -.21 & -1.99 & .05 \\
\hline$\rho$ & .09 & Openness & -.10 & -.93 & .34 \\
\hline
\end{tabular}

Dependent variable is LMX; significant at the 0.05 level; $\mathrm{R}^{2}$-coeff. determination; $\rho$-value $(\mathrm{Sig})<.05 ; \beta$-beta standard regression coefficient.

Source: Authors' calculations

The regression model for the tourism and the public sector is given in Table 4, where the criterion variable exchange leaders and followers (LMX), and a set of predictors personality dimensions.

Personality dimensions according to the model BFI have influenced the level of exchange leaders and followers in any of the examined sectors.

\section{DISCUSSION}

This study examines the relationship between personal traits according to BFI model and LMX in the tourism and the public sector. The sample taken is relatively small, 100 participants per sector and only two sectors were tested.

There are certain differences in the sectoral and gender structure of the relations of leaders and followers and personality of employees. The tourism sector is significantly different from the public sector in subordinate-supervision relation, extraversion, agreeableness and emotional stability. The level of the LMX relationships is moderate, while for those personality dimensions are small. When the gender structure, differences were demonstrated in favor of the female population for extraversion, agreeableness and conscientiousness. For all three dimensions' effect sizes are small. Average of all respondents on LMX-7 construct is 24 for tourism sector, and 20 for public sector, and it can be concluded that the relationship between the leader and follower is moderate quality of both sectors. Extraversion represents employees tend to be social, persistent, active and enthusiastic. Agreeableness indicates selflessness and understanding for others. Conscientiousness has two related aspects: performance and reliability. Neuroticism represents 
employees tend to show a low level of emotional stability and have negative experiences (anxiety, hostility, etc.) that affect the working environment. Hypothesis One is partially confirmed.

Examining the correlation between the LMX relation and all five dimensions of personality were found to be positively correlated conscientiousness and openness in the tourism sector, and extraversion in the public sector. While the negative correlation was observed between LMX and emotional stability in the public sector. All correlations are low intensity. Hypothesis Two is partly confirmed.

Regression model was determined whether the predictors of exchange leaders and followers all five dimensions of personality in both mentioned sectors. The results suggest that the personality dimensions according to the model BFI do not have prediction to the exchange level of leader-member. Hypothesis Three has not been confirmed.

\section{FUTURE RESEARCH DIRECTIONS}

The leader is the one who gives guidance, provides support, engage and empower their followers. The results in this study can be used in the work of formation of the operating team, in which they can avoid all the negative consequences that do not contribute to improving organizational performance. Although this study limited on LMX and personality traits, the results show what influences the construction of quality exchange between leaders and employees.

These results may be important for the development of LMX theory in two specific, service sectors, which have not been sufficiently studied in our environment. The number of samples and constructs (such as organization commitment, job satisfaction, etc.) should be increased, in order to examine relations more closely in the future research. More studies in this field would be useful for the LMX theory and practice.

\section{CONCLUSION}

In terms of the Serbian economy, salaries in public sector are insufficient, or regular, while in tourism sector significantly lower than the average and irregular, so that the survey does not include data on monthly income as employees in both sectors do not want to be heard.

In the tourism sector organizations with a relatively small number of employees (excluding hotels) and among them there is the possibility of frequent and close communication and without a high level of employee' extraversion. In the public sector relations are based on a hierarchy which is not a favorable environment for establishing good communication between supervisors and employees. The high level of extraversion employee is a good prerequisite for initiating communication with superiors, so that the public sector extraversion growth accompanied by growing levels of LMX. Significant correlations with extraversion dimension confirm that people with high levels of extraversion established relationships with a large number of people, which is characteristic of the public sector. In the tourism sector agreeableness was positively correlated with the level of LMX, which means when conscientiousness increases, the level of LMX increase, which is not the case in the public sector, where the correlation is not observed.

Organization in the tourism belonging to the private sector, wherein the reward is based on the working performance, which are to a certain extent based on the level of agreeableness expressed by a staff, which also influences the level of trust that has employee with a leader (that rewards 
these performance). Within the public sector, there is not a significant correlation between the level of agreeableness and LMX, which gives specific information about the fact that in the public sector are not defined in the reward system according to the progress of the working performance of employees, and to a certain extent can be made responsible superior (Government of Serbia has announced application of pay scales at all levels of government since 2017).

In the public sector, the growth of negative affectivity accompanied by declining levels of LMX, while the tourism sector there is no significant correlation between negative affectivity and the level of LMX. One of the reasons for the result obtained may be general dissatisfaction of employees in the public sector, not only in relations with superiors, but also in relations with colleagues, which negatively affective person may prevent the establishment of a relationship of trust with the supervisor and other employees.

The presence of optimism and positive emotions contribute significantly to the daily work. Negative emotionality does not allow for a high-level exchange between leaders and followers, and business outcomes are poor. In the context of public sector this dimension of personality is not desirable, because it inhibits other members of the team or organization in implementing its operating activities, and how to talk about the services sector, may suffer unpleasant consequences and the providers and users of services. Neuroticism in the public sector has a negative impact on the level of exchange of leaders and followers. In the public sector, employees are selected by competition, accompanied by formal documentation, but there is no psychological questionnaires and tests. On the other hand, employment in the tourism sector performed most frequently interview, the candidates are in hotels other than formal-working ability and psychological tests.

Openness to ideas did not show correlation with the level of LMX in the public sector, but it is positively related in the tourism sector. Jobs in the tourism sector require new ideas, but the general state of the market, as well as the weak economic power, led to the fact that managers (owners) operate in a safe (do not take risky moves in the business).

\section{REFERENCES}

Allport, G. W., \& Odbert, H. S. (1936). Trait-names: A psycho-lexical study. Psychological Monographs, 47:1, (Whole No. 211). https://doi.org/10.1037/h0093360

Barrick, M. R., \& Mount, M. K. (1991). The Big Five Personality Dimensions and Job Performance: A Meta-Analysis. Personnel Psychology, 44(1), 1-26.

Bauer, T. N., Erdogan, B., Liden, R. C., \& Wayne, S. J. (2006). A Longitudinal Study of the Moderating Role of Extraversion: Leader-Member Exchange, Performance, and Turnover During New Executive Development. Journal of Applied Psychology, 91(2), 298-310. https://doi.org/10.1037/0021-9010.91.2.298

Bernerth, B. J., Armenakis, A. A., Feild, S. H., Giles, F. W., \& Walker, H. J. (2008). The Influence of Personality Differences Between Subordinates and Supervisors on Perceptions of LMX. Group \& Organization Management, 33(2), 216-240.

Bass, B. M. (1990). From transactional to transformational leadership: Learning to share the vison. Organisational Dynamics, 18(3), 19-31.

Chamorro-Premuzic, T., \& Furnham, A. (2005). Personality and Intellectual Competence, London: Lawrence Erlbaum Associates. https://doi.org/10.4324/9781410612649 
Colquitt, J. A., LePine, J. A., \& Noe, R. (2000). Toward an Integrative Theory of Training Motivation: A Meta-Analytic Path of Analysis of 20 Years of Research. Journal of Applied Psychology, 85(5), 678-707.

Costa, E T., Jr., \& McCrae, R. R. (1988). Personality in adulthood: A six-year longitudinal study of self-reports and spouse ratings on the NEO Personality Inventory. Journal of Personality and Social Psychology, 54, 853-863.

Costa, E T., Jr., \& McCrae, R. R. (1992). Revised NEO Personality Inventory (NEO-PI-R) and NEO Five-Factor Inventory (NEO-FFI). Professional manual. Odessa, FL: Psychological Assessment Resources.

Dansereau, F., Graen, G., \& Haga, W. (1975). A vertical dyad linkage approach to leadership with informal organizations. Organizational Behavior and Human Performance, 13, 4678.

Day, D. V., \& Miscenko, D. (2015). Leader-Member Exchange Theory (LMX): Construct evolution, contributions, and future prospects for advancing leadership theory. In T. N. Bauer \& B. Erdogan (Eds.). The Oxford Handbooks of leader-member exchange. Oxford, England: Oxford University Press. https://doi.org/10.1093/oxfordhb/9780199326174.001.0001

Dienesch, R. M., \& Liden, R. C. (1986). Leader-member exchange model of leadership: A critique and further development. Academy of Management Review, 11, 618-634.

Erdogan, B., \& Bauer, T. N. (2015). Leader-member exchange theory. International Encyclopedia of the Social \& Behavioral Sciences, Second Edition, 641-647.

Erdogan, B., \& Liden, R. C. (2002). Social exchanges in the workplace: A review of recent developments and future research directions in leader-member exchange theory. In L. L. Neider \& C. A. Schriesheim (Eds.): Leadership. Greenwich, CT: Information Age. 65-114.

Grant, S., \& Langan-Fox, J. (2007). Personality and the occupational stressor-strain relationship: The role of the big five. Journal of Occupational Health Psychology, 12, 20-33.

Goldberg, L. R. (1990). An Alternative "Description of Personality": The Big-Five Structure. Journal of Personality and Social Psychology. 59(6), 1216-1229. https://doi. org/10.1037//0022-3514.59.6.1216

Graen, B. G., \& Cashman, J. (1975). A role making model of leadership in formal organizations: A developmental approach. In J. Hunt \& L. Larson (Eds). Leadership Frontiers. Kent, OH: Comparative Administration Research Institute, Kent State University.

Grean, B. G., \& Scandura, T. A. (1987). Toward a psychology of dyadic organizing. Research in Organizational Behavior, 9, 175-208.

Graen, B. G., \& Uhl-Bien, M. (1995). Relationship-Based Approach to Leadership: Development of Leader-Member Exchange (LMX) Theory of Leadership over 25 Years: Applying a Multi-Level Multi-Domain Perspective, Management Department Faculty Publications, Paper 57, Nebraska.

John, O. P., \& Srivastava, S. (1999). The Big Five trait taxonomy: History, measurement, and theoretical perspectives. In L. A. Pervin \& O. P. John (Eds.). Handbook of personality: Theory and research. New York: Guilford Press. 2, 102-138.

John, O. P., Naumann, L. P., \& Soto, C. J. (2008). Paradigm shift to the integrative Big Five trait taxonomy: History, measurement, and conceptual issues. In O. P. John, R. W. Robins, \& L. A. Pervin (Eds.). Handbook of personality: Theory and research. New York, NY: Guilford, Vol. 3, 114-158.

Judge, A. T., Bono, E. J., Ilies, R., \& Gerhardt, W. M. (2002). Personality and Leadership: A Qualitative and Quantitative Review. Journal of Applied Psychology, 87(4), 765-780. https://doi.org/10.1037//0021-9010.87.4.765 
Liden, R. C., Sparrowe, R. T., \& Wayne, S. J. (1997). Leader-Member Exchange Theory: The Past and Potential for the Future. In G. R. Ferris (Ed.), Research in personnel and human resources management. Greenwich, CT: JAI Press, Vol. 15, 47-120.

Louis, M. R., (1980). Surprise and Sense Making: What Newcomers Experience in Entering Unfamiliar Organizational Settings. Administrative Science Quarterly, 25(2), 226-251. https://doi.org/10.2307/2392453

McCrae, R. R., \& Costa, P. T. (1990). Personality in adulthood. New York: Guilford.

McCrae, R. R., \& John, O. P. (1992). An introduction to the Five-Factor Model and its applications. Journal of Personality, 60(2), 175-215. https://doi.org/10.1111/j.1467-6494.1992. tb00970.x

Meyer, J. P., \& Allen, N. J. (1991). A three-component conceptualization of organizational commitment. Human Resource Management Review, 1, 61-89.

Piedmont, R. L., McCrae, R. R., \& Costa, P. T., Jr. (1991). Adjective check list scales and the five-factor model. Journal of Personality and Social Psychology, 60, 630-637.

Schyns, B., Maslyn, J. M., \& Van Veldhoven, M. P. M. (2012). Can some leaders have a good relationship with many followers?: The role of personality in the relationship between Leader-Member Exchange and span of control. Leadership \& Organization Development Journal, 33(6), 594-606. http://dx.doi.org/10.1108/01437731211253046

Teng, C. (2008). Personality Differences Between Online Game Players and Non-Players in a Student Sample. Cyber Psychology and Behavior, 11(2), 232-234.

Uhl-Bein, M. (2006). Relational Leadership Theory. Exploring the social processes of leadership and organizing. Leadership Quarterly, 17(6), 654-676.

Wayne, S. J., \& Green, S. A. (1993). The effects of leader-member exchange on employee citizenship and impression management behaviour. Human Relations, 46, 1431-1440.

Yukl, G. (1998). Leadership in organizations. Upper Saddle River, NJ: Prentice Hall. 